\title{
PERCEPTION OF RESIDENTS IN RESIDENTIAL HIGH-RISE BUILDINGS IN TERM OF SUSTAINABILITY IN ERBIL CITY
}

\author{
WEZHA HAWEZ B AIZ ${ }^{1}$ and ERCAN HOSKARA \\ Dept. of Architecture, Faculty of Architecture, Eastern Mediterranean University, North Cyprus, \\ Famagusta 99450, Mersin 10, Turkey
}

(Accepted for Publication: December 8, 2020)

\begin{abstract}
Land price, global icon, and rising population are among the obvious factors to encourage mega structures in Erbil city. Consequently, high-rise and tall buildings have developed and spread in various ways in the city and living in apartments is currently a lifestyle phenomenon. The main purpose of this paper is to investigate the high-rise residential satisfaction. Through it, those factors have affected on the satisfaction level of residences in residential high-rise buildings of a subset of subjects are analysed in the elected two residential high-rise buildings in the city. The background, through literature review, focuses on determinants sustainability that have an impact on residential satisfaction as the design of the units, building material qualities, security and safety, confidentiality and privacy, socio-cultural aspects, and community. In another word, this study focuses on the sustainable indicators in high-rise residential buildings. The main method for understanding the perception of residents is questionnaires, which related to the apartment, the building, and the surrounding area, with between 18 and 80 years of age in the sample population. The findings demonstrated general significant factors of satisfaction in the high-rises as architectural designs of apartments, space arrangement, and facilities.
\end{abstract}

KEYWORDS: Socio-economic indicator, environmental aspects, facility, comfort level, residential towers.

\section{INTRODUCTION}

Satisfaction of residents in high-rise flats Nhave been occurring as motivating frameworks in individual living gratification and psychology, community lifestyle, well-being and health. Housing is related as a very important concern for a large section of people who are residing in big cities. To accommodate a large number of people in a limited space the planners and architects have created high rise apartments. Migration in metropolitan cities has contributed to a large number of high-rise apartments.

As clear that in some places around the world, the high-rise residential complexes are fulfilling the affordable housing, demands of a large

wezha.hawez@gmail.com;

${ }^{1}$ Corresponding author: Faculty of Architecture, Eastern Mediterranean University, North Cyprus, Famagusta 99450, Mersin 10, Turkey

population and providing a large number of ultra-modern facilities for residents. While the more specific reasons for constructing high-rise buildings differ, there are factors that apply more directly to the construction of buildings with over 12 floors in Erbil City as limited available land, as a product of need: The mass migration of people from rural to urban areas, individuals and designers alike are also in a race to find a place for their services in the highly competitive marketplace, power, status, and prestige, no strategies, plans, and designs are capable of perfectly limiting the potential height of a building, and using high-rise buildings as an attractive construction in a big project.

ercan.hoskara@emu.edu.tr 
Focusing on mega-structures in this development, design tall and high-rise buildings are not just design and solve the function inside the building and putting one over the other. Otherwise, there are many other sides that have to be carried by the architect about it. And as known that mega-structure brings impacts around with them as principles, strategic and regional levels. In another word, the enormous numbers of people loaded on a high building will overburden public transport, roads and utilities, especially at peak times (Ibrahim, 2007). In addition, there have been no significant results in the construction of high-rise buildings, and efforts are resumed after the energy crisis. Many countries and universities, especially in the North of Iraq, there are many problems that can be seen clearly. Because of the absent regulations and non-welling recognizes the potential benefits it can be seen that mega-structures lack an overall strategy for bettering the lives of the city's residents, their health, or the economy. This implies a lack of direct concern with sustainability issues and environmental-friendliness. There is no debated that, these case products many other problems and difficulty to themselves and their surroundings in the city such as dark caverns, overheating in summer, lack of rules and regulation vision angle, very high energy consumption level, the balance between green area and mass area, too expensive, environmental pollution.

The sudden expansion of Erbil's construction sectors in the past two decades, particularly in the areas of housing and building developments, has been a primary driver of economic growth. However, this expansion has also been accompanied by a host of other economic, social, and environmental problems, which threaten the long-term sustainability of the city. These problems increase the necessity not just for social and political solutions, but economic ones as well, and the adoption of sustainability criteria by the construction sector is one method of achieving this. These above cases are non-acceptable either in academic study or practice, especially if focused on the very primary necessity of tall buildings. In Kurdistan region in high rise residential apartment buildings so few users' satisfaction studies were carried out.

Thus, architectural design is directly relevant to residential satisfaction. The significant contribution of this paper is the vision, however, that does not limit 'residential satisfaction' within the boundaries of the flat. However, it defines in the larger context including the building within which the flat is situated and the environment exterior of the building. Thus, the ultimate scope of this research is to identify features of Residences satisfaction that should be taken into account in the methodological approach and design. It has also aimed at uncovering ways to enhance comfort, adapting the buildings to societal and health requirements, and reduce their overall energy consumption. Using the pillars of environmental, economic and social sustainability, it utilizes sustainability as an outline for consolidating the pitfalls of those kinds of building development. In this research, the key and interactional effects on the evaluation of complex facilities of employment status, influencing factor for choosing flat in high rise, neighborhood relationship, social support health, happiness and residential satisfaction are examined.

This research is focused on residences' replies and focuses on the administration of a survey questionnaire to their apartment, their building and their community. The questionnaire survey is long since architectural research has now found that the satisfaction of residents is associated, not only with residence itself, but also with the construction of apartments and the environment.

\subsection{Satisfaction of residents in high-rise} apartments:

wezha.hawez@gmail.com; ercan.hoskara@emu.edu.tr

${ }^{1}$ Corresponding author: Faculty of Architecture, Eastern Mediterranean University, North Cyprus, Famagusta 99450, Mersin 10, Turkey 
Residential satisfaction also requires happiness in the environment and neighborhood and is more than a structure of physics (Garling, 2002). The degree of satisfaction often depends on other external factors such as economic benefits, quality of life change, economic development and environmental concerns. The resident's satisfaction is a feeling that the group fulfills the residents' personal objectives and needs and that a group connection is felt. A multidimensional system centered on the social environment, such as the physical environment and property, as well as the provision of community resources and the quality of housing. (James et al., 2009; Garling, 2002; Grillo et al., 2010).

Sustainable high-rise buildings interim of sustainable architecture and high-rise district urban design are primary growth patterns (Wood and Oldfield 2015). Only if the urban context around is sustainable can sustainable architecture make sense (Gissen, 2003). Mega structures as a high-rise building are no longer viewed as isolationist construction. There is no debate that urban area having a high-rise and skyscrapers are not like those areas that the majority of the buildings are low-rise buildings. Tall buildings are a phenomenon of the city now and dose not going individually without effecting on the urban planning. In terms of how well this actually works in High-rise building statuses in the equilibrium of sustainability, these ideas can be taken and incorporated in high-rise buildings and they are important for sustainability. Severe doubts have been raised by many academics.

According to the aspect and principles of sustainable building and there are many classification and key features under different titles. Economic sustainability, environmental sustainability and social sustainability are the common among them. Also, it is known as three piles (3P) or three E (3E) as well as three dimensions

\subsubsection{Social dimension}

Even when a high-rise dwelling is ideal for single individuals and couples, for a family with children it may become less ideal. Many sociologists claim that people can be claustrophobic by developing a rat-cage attitude in their setting for big buildings. This is reasoned that living in low-level is similar to nature and offers a better social life for the community. As systems are growing bigger and bigger, taller and taller and height of the floor level increases the tenants become out of touch with the ground reality below. The new research on the quality of the environment and neighborhood and mental wellbeing is demonstrated by community impact on mental health for the children (Leventhal \& Brooks- Gunn, 2000). The question of how comfort should be distinct leftovers unanswered (Butkovic, et al., 2012; Dodge et. al., 2012). In the current psychology research, there are therefore several broad, inconsistent definitions. The concept of psychological well-being or the elements highlighted change according to the context in which it is analyzed as a multi-dimensional construction (Dodge et al., 2012). The initial findings on influencing factor for choosing flat in high rise are related to facilities given in the complex (Haarhoff et al.,2012). Syme et al. (2004) discovered that citizens living in high rise rated highest satisfaction to the closeness of Facilities they enjoy every day; stores, restaurants and cafe, classrooms, places of employment, public transportation and public areas included.

\subsubsection{Economic dimension}

One of the principles of sustainability used for building construction is aimed at optimizing productivity and reducing financial costs. Most organizations, both in the private and in the public, decide on construction expenditure on the basis of initial building cost projections, with little to no regard for costs of running and maintaining the building over the life of the

wezha.hawez@gmail.com; ercan.hoskara@emu.edu.tr

${ }^{1}$ Corresponding author: Faculty of Architecture, Eastern Mediterranean University, North Cyprus, Famagusta 99450, Mersin 10, Turkey 
building (Woodward, 1997). There is a considerable amount of evidence. According to Giudice, et al (2005) design decisions involve choosing the structure, building materials and building installations, often followed by investment mistakes, through weak economic decision-making. The economic function of buildings should be considered during the entire construction process and even during their useful lifespan in terms of repair and restoration. The cost of the life cycle is the initial expense, using cost and the cost of recovery. (Akadiri, et al., 2012).

High-rise construction is extra costly buildings than the low-rise or single-story buildings because of many factors that they have explained some of them, in another word, many other factors exist that tell the engineers the mega structure need more cost. High-rise buildings often require costly vertical transport, including lifts and escalators. Typically, people do not want to walk up more than several stories and do not accept long lifts. In order to keep the elevators waiting for a certain number of seconds - roughly 30 seconds for commercial office buildings, and 45 seconds for residential buildings - engineers determined the necessary number of elevators (Al-Kodmany, 2015).

In addition, in hot Summer and indoors heat, cold winter rooms, sky grinders need expensive mechanical, electrical and plumbing systems as well as tremendous energy to generate power to the higher floors.

Al-Kodmany \& Ali (2013) highlighted that according to the floor spaces, the relative available floor space is about $10 \%$ less than in case of low-rise, merely because of the core and the vertical transportation system. Because skyscrapers are increasingly hosting many functions (e.g. residential, commercial, hotel) more elevators are required by architects. Elevators thus add significant costs to the house, but also use the enormous space available.
In general, they can be controlled under initial, in use, and recovery cost strategies that each of them could be drive by their various methods (Akadiri, et al, 2012). Hua \& Kiefer (2007) pointed out purchasing an apartment in any type of residential dwellings is one of the furthermost important economical options because it needs a lot of knowledge about its characteristics.

\subsubsection{Environment dimension}

High-rises focus more residents, properties and services, which render floods more disruptive and costly. Applying structural flood mitigation measures in compact cities, including building walls, is challenging, and may clash with existing infrastructure and disrupt the connection between sidewalks and ground floors creating unequal pedestrian environments (Lynch, 2015).

Because of feature of mass, those kinds of building, high-rise buildings, are one of the largest consumers of electricity, material resources and water because of its scale, and is a major contaminant. In order to make sure that the occupants have comfortable rooms indoors, architects create a low - temperature and natural ventilation skyscrapers that hold owners of buildings in continuously warm and cool spots (winter and summer respectively). The energy needed to heat and cool these skyscrapers are therefore not only costly, but also harms the environment through the generation of massive dioxide (Heinonen, et al, 2011). In open areas like squares, corridors, exits, corners and spaces between buildings, wind acceleration is evident (Kawamoto, 2016).

Also, waste management's another issue in these principles, high-rise buildings produce big amounts of waste as huge people reside in them. On a regular, an apartment unit disposal rate is approximately 1 ton annually. While this amount of waste is not different from a low-rise residential building, it is more difficult to collect waste in high hazards than in lower risks. As such, waste collected by carriers must occur

wezha.hawez@gmail.com; ercan.hoskara@emu.edu.tr

${ }^{1}$ Corresponding author: Faculty of Architecture, Eastern Mediterranean University, North Cyprus, Famagusta 99450, Mersin 10, Turkey 
about once a week, a law that extends to single-family pickup of residential waste (Al-Kodmany, 2015). Also, sustainable site, green area and the building envelope are other principles

\subsection{Concerns of high-rise building}

The design and concept of high-rise building have many features and amenities, which make them distinctive and contrasting in competition with other buildings. This mega structure is the product of modern construction. The buildings are considered. It is packed with specialized technologies and critical components. Despite the positive approach to high-rise living, a number of concerns have been associated with it (Yuen 2011). Nevertheless, it is important to identify the issues that contribute to the concerns in high-rise using because they need to be mitigated in order to promote economically, socially and environmentally sustainable practices. A number of concerns related with living in high-rise living can be summarized in Fire safety and Fire Incidences (Ahrens, 2016), Vertical transportation, Who the neighbours are,
Accidental falls from the high-rise, Power failure, Structural safety, Building height, Behavioural problem in children: (Salassa and Zapala, 2009 and Ahrens, 2016), Less social interaction: (Salassa and Zapala, 2009 and Auclair and Hertzog, 2015), Lack of privacy, Suicide: (Turner and Wigfield,2017), Family and Community Living (Story and Saulfeb, 2015; Prezza, et al, 2001), Human Scale (Al-Kodmany and Ali, 2013), Placelessness and the Public Realm (Al-Kodmany, 2018), Preservation and Blocking Views, Window Cleaning, Repair, and Maintenance, Health and Well-Being: (Prezza, et al., 2001), Space and location (Watts and Langdon, 2010).

\section{MATERIAL AND METHODS}

\subsection{Site Study}

According to (Climate Consultant 6.0) Erbil is a Kurdistan region's main city and Kurdistan region of Iraq's capital. Erbil is located 453 meters above sea level with latitudes $36.2^{\circ}$ North and $44.02^{\circ}$ of Longitude Eastern time zone figure 1.

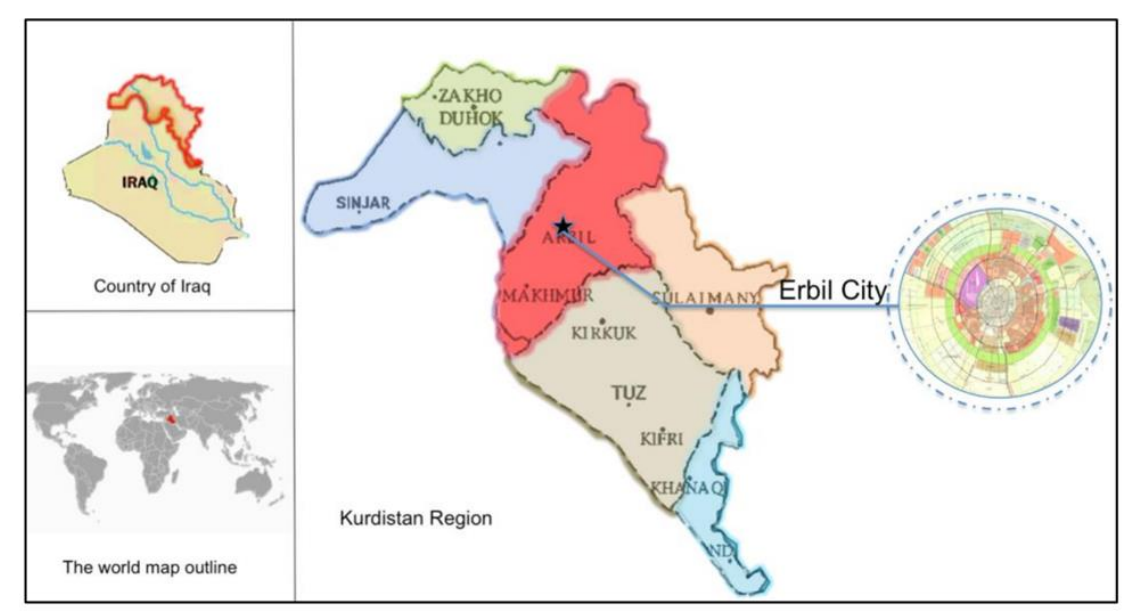

Fig. (1): Study area/ Erbil City (by author)

As Dizayee (2014) states that over the last two decades, the population and infrastructure of Erbil have developed tremendously. The population of Erbil rose annually by $2.9 \%$
(Dizayee, 2014) and according to (Erbil Governorate Profile, 2015) reached to 1.530 .722 in 2015

wezha.hawez@gmail.com; ercan.hoskara@emu.edu.tr ${ }^{1}$ Corresponding author: Faculty of Architecture, Eastern Mediterranean University, North Cyprus, Famagusta 99450, Mersin 10, Turkey 
Erbil as an old city experienced rapid increase and notable growth over different time periods and various stages following the establishment of Iraq in1920. Especially after 2003 when the city enjoyed more stability and a safer climate in comparison with the other urban in Iraq, autonomous management of resources and revenues and economic prosperity has enabled the area to speed up its recovery and development, (Yasin, 2011). The castle 's form and height formed the urban layout of the areas surrounding it as clustered rings and a radial axis. In that sense, Erbil's urban planning has always centered on the citadel during its antiquity.

Latest projects and modern compounds around the old city have been steadily unhappy with the lack of strategy (Ibrahim et al., 2015). The increasingly unplanned growth is incidental and does not represent a sustainable solution, but one which is marked by uncertain effects of the growing population and economic assets (Rydin, 2010).

\subsection{Reviews of Questionnaire}

the method that will be used in this paper for approaching the main aim is questioners. More clearly, to understand the satisfaction level of users about the living places, comfortable life and qualities, some questioners were distributed among the users of Erbil's high-rise buildings. The survey questionnaires were developed in English and Kurdish to assess the respondent's satisfaction level with regard to amenities available in the complex, community lifestyle, provision of social, health and well-being, psychological well-being, and the satisfaction and agreement of the residents of the complex. The questions have been classified in to four parts that they are:

First part: participant background and building specifications.

Second part: Environmental aspects that related to the user's satisfaction of living with the environmental issues.

Third part: Socio-cultural aspects to investigate the user's satisfaction on the socio-cultural issues of their buildings and unit.

Forth part: Economical Aspects to examine the level of affordability on the economic issues

\subsection{Cases study}

Escan Towers (comprising 27 floors, 1 underground floors, and $90 \mathrm{~m}$ height)

Quattor tower: it is four (contains 350 apartments in each) towers together in Erbil, comprising 31 floors, 3 underground floors and a $103 \mathrm{~m}$ height (figure 2).

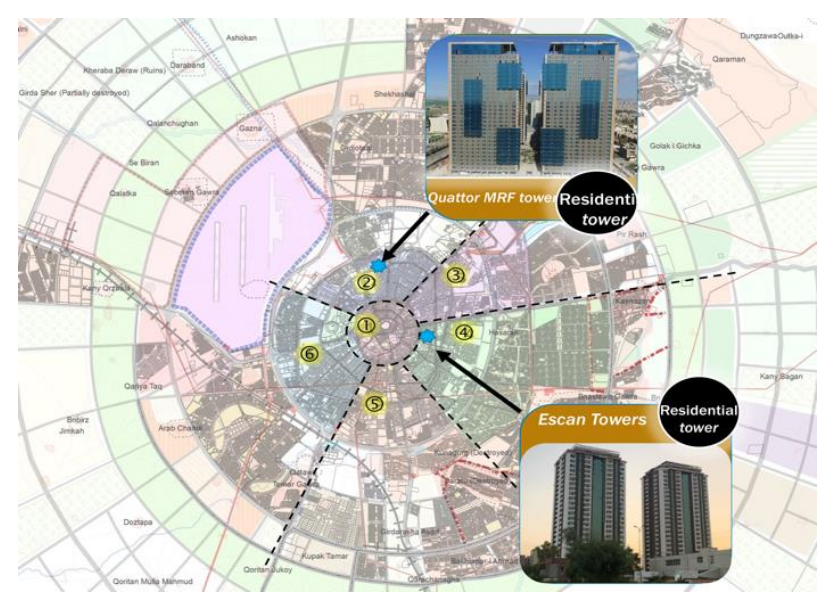

Fig. (2): Location of both cases study in Erbil city (by author)

wezha.hawez@gmail.com; ercan.hoskara@emu.edu.tr

${ }^{1}$ Corresponding author: Faculty of Architecture, Eastern Mediterranean University, North Cyprus, Famagusta 99450, Mersin 10, Turkey 


\section{- Sample size}

Regarding to Strauss and Corbin (1998), the calculation that should be used to compute the size of sample size for infinity populations or residents

$S=Z 2 * P(1-P) / M 2$

Where:

$S=$ sample Size of infinite population

$\mathrm{Z}=\mathrm{Z}$ score

$\mathrm{P}=$ population proportion

$\mathrm{M}=$ Margin of error

If we consider $95 \%$ level of confidence, Z-Score equal to 1.96

Then the amount of Margin Error is a small that is allowed for in caws of the inaccuracy or alteration of circumstance. Commonly, $\mathrm{M}=0.05$ if the taken margin of error is $5 \%$

In this case Sample Size becomes:

$\mathrm{S}=(1.96)^{2} * 0.5 *(1-0.5) /(0.05)^{2}$

$\mathrm{S}=3.8416 * 0.25 / 0.0025$

$\mathrm{S}=384.16$ for Margin error (10\%), $\mathrm{S}=96.02$

Then for adapting the representative sample to the appropriate population
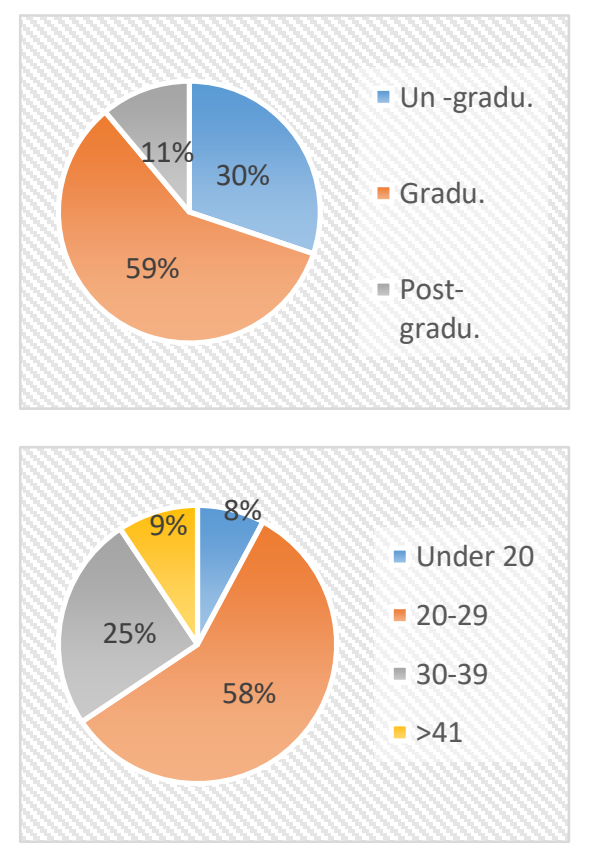

(A) Escan towers
The same formula for sample size modified

Attuned sample size $=(\mathrm{S}) /[1+$ (S-1)/population]

- For Escan Towers: Adjusted sample size = $(96.02) /[1+(96.02-1) / 192]=64$

- Quattor tower: Adjusted sample size $=(96.02) /$ $[1+(96.02-1) / 350]=76$

Regarding to method of result evaluation and analyzing, all the data from the questionnaires were analyzed using different statistical methods in SPSS. Details of the data analysis are provided later on as the results are discussed.

\section{RESULTS}

\section{- Personal Information of the participant}

A total of 34Males and 30 Females who are owners and tenant of the flat in high rise residential complex were randomly selected from Escan tower and 33 males and 43 females for MRF tower. It means that the majority of users are graduated, young and male.
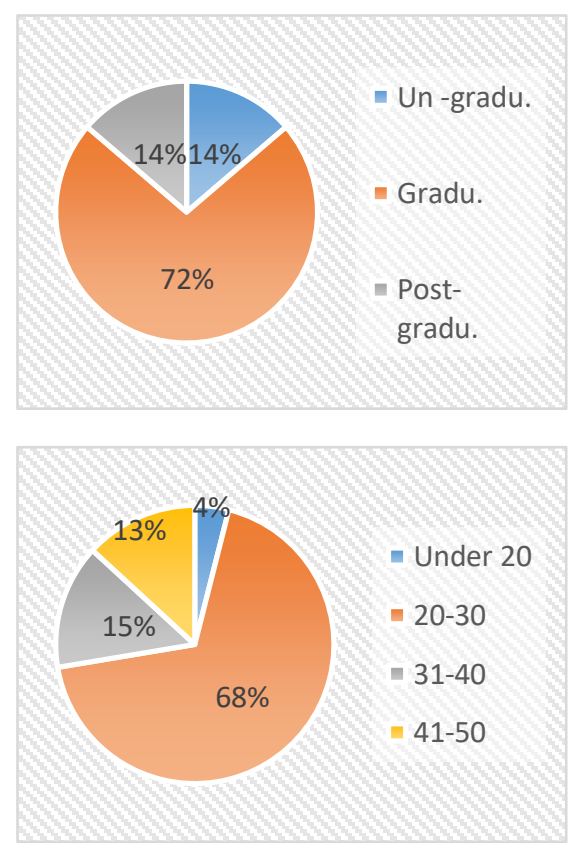

(B) MRF towers

Chart (1): Descriptive statistics frequencies of the demography of participants.

wezha.hawez@gmail.com; ercan.hoskara@emu.edu.tr

${ }^{1}$ Corresponding author: Faculty of Architecture, Eastern Mediterranean University, North Cyprus, Famagusta 99450, Mersin 10, Turkey 
- Level of satisfaction regarding to environmental, socio-cultural, and concern of high-rise buildings aspects

For an understanding of level of satisfaction, the respondents in each project were asked about their comfort level according to various aspects of environmental, social and concern of high-rise buildings. According to comfort level of environmental, social and cultural aspects there are five indicator level where " 1 " indicated "not satisfied" and " 5 " indicated "extremely satisfied" were the base of answers.

Table (1): Level of satisfactions of environmental, social aspects with concern of high-rise buildings by descriptive statistics frequency analysis (field survey)

\begin{tabular}{|c|c|c|c|c|}
\hline \multirow[b]{2}{*}{ Aspects } & \multicolumn{4}{|c|}{ Descriptive Statistics - Escan towers } \\
\hline & Min. & Maxi. & Mean & Std. Dev. \\
\hline \multicolumn{5}{|c|}{ Environmental dimension } \\
\hline Location and sit management & 2 & 5 & 2.1 & .833 \\
\hline Light and ventilation & 3 & 4 & 2.02 & 1.103 \\
\hline Water & 1 & 4 & 2.85 & 1.32 \\
\hline Noise & 1 & 4 & 3.28 & 1.17 \\
\hline Insulation & 2 & 4 & 3.76 & 1.17 \\
\hline Pollution & 1 & 4 & 2.76 & .887 \\
\hline Building material & 1 & 5 & 2.28 & 1.21 \\
\hline Finishing material & 2 & 5 & 2.14 & 1.132 \\
\hline \multicolumn{5}{|c|}{ Social dimension } \\
\hline Entrance and lobby & 1 & 4 & 3.22 & 1.02 \\
\hline Plan and size & 2 & 5 & 3.12 & 1.014 \\
\hline Design of interior & 1 & 5 & 2.71 & .978 \\
\hline View quality & 2 & 5 & 3.31 & 1.106 \\
\hline Privacy & 1 & 5 & 2.77 & 1.115 \\
\hline Space for communication & 1 & 3 & 2.13 & .586 \\
\hline Children's playground & 1 & 4 & 1.52 & .850 \\
\hline Safety for children & 1 & 4 & 1.37 & 1.041 \\
\hline Facility & 1 & 4 & 1.29 & .934 \\
\hline Disability features & 2 & 5 & 3.33 & 1.011 \\
\hline Capacity of car park & 1 & 5 & 2.36 & .844 \\
\hline \multicolumn{5}{|c|}{ Concerns of high-rise building } \\
\hline Elevator quality & 1 & 4 & 2.88 & .986 \\
\hline Wafting for elevators & 2 & 5 & 2.80 & .923 \\
\hline Falls by accident & 1 & 4 & 2.45 & 1.012 \\
\hline Safety from fire & 1 & 5 & 2.68 & 1.144 \\
\hline Safety for avoiding crime & 1 & 4 & 2.15 & 1.114 \\
\hline Falls by suicide & 1 & 5 & 2.32 & 1.218 \\
\hline Mental health & 2 & 5 & 2.13 & 1.101 \\
\hline
\end{tabular}

wezha.hawez@gmail.com; ercan.hoskara@emu.edu.tr

${ }^{1}$ Corresponding author: Faculty of Architecture, Eastern Mediterranean University, North Cyprus, Famagusta 99450, Mersin 10, Turkey 


\begin{tabular}{|c|c|c|c|c|}
\hline \multicolumn{5}{|c|}{ (B) Descriptive Statistics - MRF towers } \\
\hline Aspects & & Maxi. & Mean & Std. Dev. \\
\hline \multicolumn{5}{|c|}{ Min. } \\
\hline \multicolumn{5}{|c|}{ Environmental dimension } \\
\hline Location and sit management & 1 & 4 & 2.7 & .824 \\
\hline Light and ventilation & 1 & 5 & 3.11 & .954 \\
\hline Water & 1 & 5 & 2.44 & .989 \\
\hline Noise & 1 & 4 & 2.56 & .767 \\
\hline Insulation & 1 & 4 & 2.45 & 1.347 \\
\hline Pollution & 2 & 5 & 2.85 & 1.121 \\
\hline Building material & 1 & 5 & 2.22 & 1.243 \\
\hline Finishing material & 2 & 4 & 2.54 & .865 \\
\hline \multicolumn{5}{|c|}{ Social dimension } \\
\hline Entrance and lobby & 1 & 5 & 2.97 & 1.232 \\
\hline Plan and size & 1 & 5 & 3.08 & 1.074 \\
\hline Design of interior & 1 & 5 & 3.21 & .889 \\
\hline View quality & 1 & 5 & 2.13 & 1.122 \\
\hline Privacy & 1 & 4 & 2.57 & 1.313 \\
\hline Space for communication & 1 & 5 & 3.23 & .756 \\
\hline Children's playground & 1 & 4 & 2.41 & .930 \\
\hline Safety for children & 1 & 4 & 2.47 & 1.134 \\
\hline Facility & 1 & 5 & 1.30 & .920 \\
\hline Disability features & 2 & 5 & 3.33 & 1.237 \\
\hline Capacity of car park & 1 & 4 & 2.34 & 1.231 \\
\hline \multicolumn{5}{|c|}{ Concerns of high-rise building } \\
\hline Elevator quality & 1 & 4 & 3.21 & .886 \\
\hline Wafting for elevators & 2 & 5 & 3.10 & .800 \\
\hline Falls by accident & 1 & 5 & 2.78 & 1.021 \\
\hline Safety from fire & 2 & 5 & 3.70 & 1.243 \\
\hline Safety for avoiding crime & 1 & 5 & 2.45 & 1.154 \\
\hline Falls by suicide & 1 & 5 & 2.54 & 1.011 \\
\hline Mental health & 1 & 4 & 2.49 & .986 \\
\hline
\end{tabular}

It can be noted that, from the above tables, the respondents were not satisfied with majority of aspects in each of those different sustainable indicators. There were only six aspects in MRF towers and eight aspects in Escan towers shown as a very satisfied level for the respondents.

wezha.hawez@gmail.com; ${ }^{1}$ Corresponding author: Faculty of Architecture, Eastern Mediterranean University, North Cyprus, Famagusta

\section{- Level of satisfaction regarding to different economic aspects}

The respondents were asked to show their level of affordability according to several issues of economy dimension regarding to their apartment. There are five ranks to show the levels where " 1 " indicated "not Affordable" and "5" indicated "extremely Affordable" were the base of answers.

ercan.hoskara@emu.edu.tr 
Table (2): Affordability level of descriptive statistics frequencies analysis (field survey)

(A) Descriptive Statistics -Escan Towers

$\begin{array}{llll}\text { Min } & \text { M } & \text { Mea } & \text { Std. Dev. } \\ & \text { ax } & n & \end{array}$

\begin{tabular}{lllll}
\hline For rent and sell & 1 & 5 & 3.18 & 1.142 \\
\hline Water & 2 & 5 & 3.13 & 1.101 \\
\hline Gas and electricity & 1 & 5 & 2.25 & 1.250 \\
\hline Sanitary & 1 & 5 & 2.33 & 1.189 \\
\hline Cleaning and Service & 1 & 5 & 2.77 & 1.511 \\
\hline
\end{tabular}

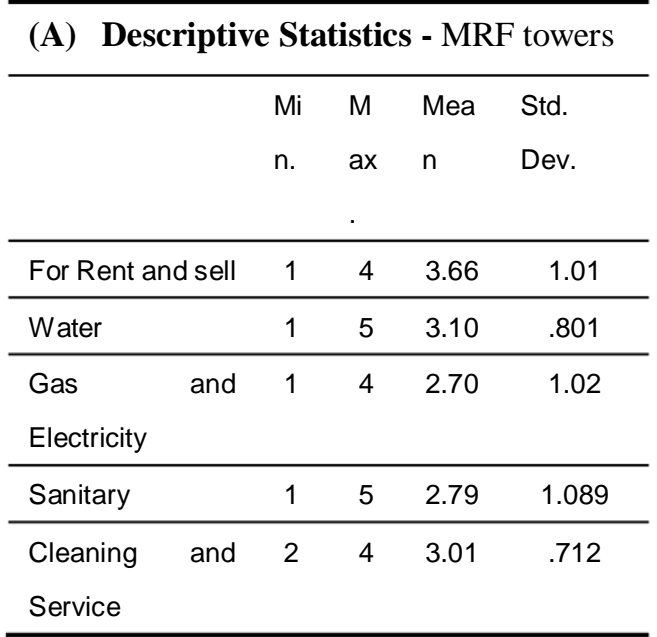

From the table water cost and for rent and sell were affordable in both towers and cleaning and services in MRF tower were affordable.
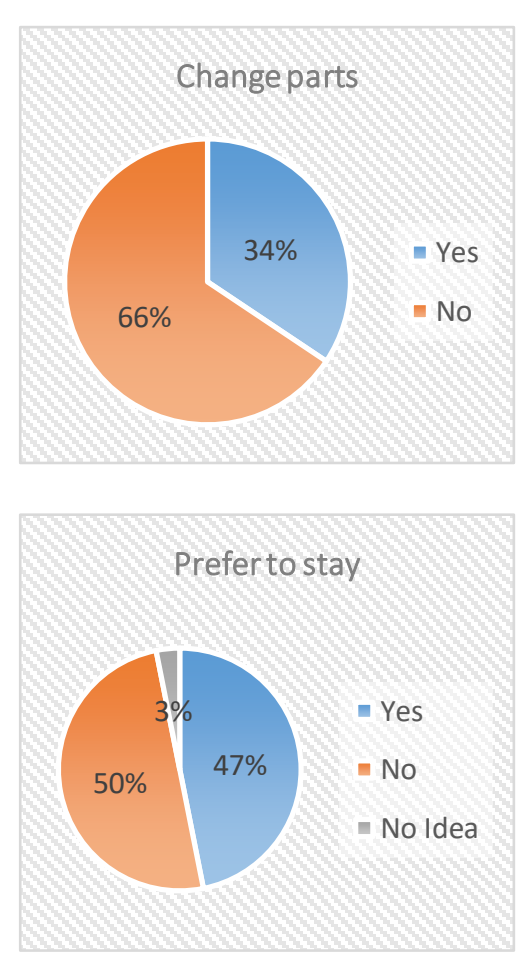

(A) Escan towers
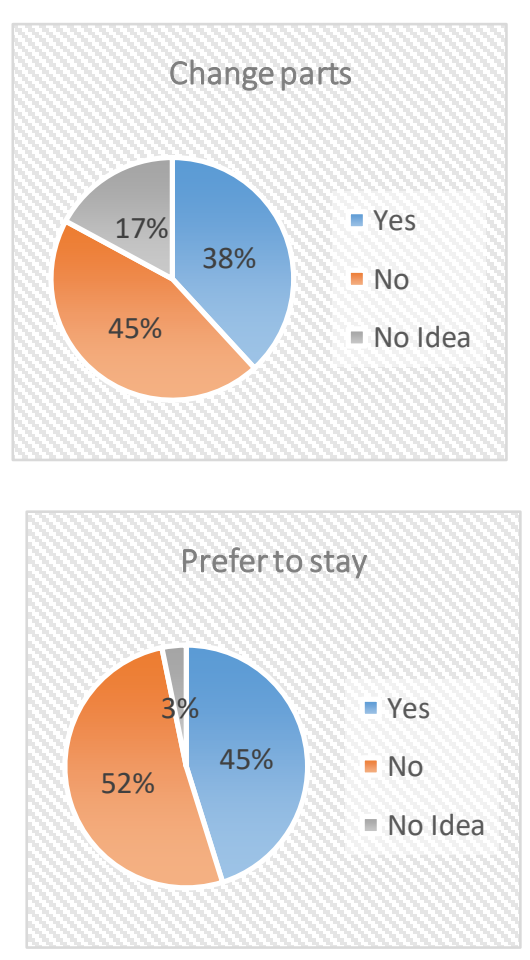

(B) MRF towers

Chart (2): The percentages of change parts and prefer to stay by respondents

wezha.hawez@gmail.com; ercan.hoskara@emu.edu.tr ${ }^{1}$ Corresponding author: Faculty of Architecture, Eastern Mediterranean University, North Cyprus, Famagusta 99450, Mersin 10, Turkey 


\section{DISCUSSION}

The residential high-rise facility in Erbil city has now come into existence is obvious. Not only does the control disparity exist, but it is also an obstacle to successful deployment. Note that the occupants in quattro towers were still less happy with water quality, insulation and building material regarding to environmental aspects. Also, view quality, playground and safety for children, facility and car park capacity regarding to the social dimension. Additionally, safety in avoiding crime and mental heal regarding to the concerns of high-rise building.

In other side, the residents in Escan tower still unhappy with tower location, light and ventilation, building and finishing material in environmental aspects, view quality, communication space, playground and safety for children, facility and carparks of socio culture dimensions, and fall by accident and suicide, avoiding crime, and psychological health.

In this study, the key outcomes indicate that a lot of tenants have recently taken up residence complexes that are newly constructed. Increased residents have indicated that their group life is fulfilled. In addition, more residents reported high residential satisfaction and high happiness rates regarding to some aspects. The building also resulted in qualitative variations between the pedestrian community and the external resident environment in terms of essentials as roads, open spaces and outdoor areas as well as position of parking in residential areas as it has been mentioned above.

In high-rise residential buildings, Erbil culture and values are not reflected. The significance of the relationship between the high-rise houses and the world around them has not been investigated.

Although lack of visual privacy, children's playgrounds and community space have been identified, no study to provide answers to these situations has been undertaken. The car parking problem was another significant source of discontent in Erbil.

\section{CONCLUSIONS}

In conclusion, the outcome demonstration that the design of the flat buildings and residences should be designed with full awareness of the needs and demands of the residents, because they are the true consumers. It is also important not to forget that the area where the people live is not confined to the apartment. The concept of apartment buildings and environment should be extended.

All these steps impact user satisfaction. Although the architect-designer does not control all these phases directly, the architectural design of the project marks the first step. Therefore, the architect cannot control, but decide many of the factors which determine the satisfaction of the resident. The architect should, however, explicitly and exclusively define aspects of resident satisfaction.

Differences in methods for housing construction seem to impact the residential quality, mostly with characteristics of the urban space system. In terms of amenities, quarters and safety in decreasing order, total residence satisfaction was most influenced. As the influencing factors of residential satisfaction are primarily linked to the external space between residential housing, and neighborhood residential areas, the first priority for the enhancement of residential satisfaction should be the environmental improvements in external residential areas.

Applying design guides on the resident protection of zones and areas, improving the living spaces and built environment with building elements and blocks and political and regulatory use classification supplementation, will be necessary in a long time, for residential and offices mixed zone sustainable long-term.

wezha.hawez@gmail.com; ercan.hoskara@emu.edu.tr

${ }^{1}$ Corresponding author: Faculty of Architecture, Eastern Mediterranean University, North Cyprus, Famagusta 99450, Mersin 10, Turkey 


\section{REFERENCES}

Ahrens, M. (2016). High-rise building fires. NFPA (National Fire Protection Association): Quincy, MA, USA.

Akadiri, P. O., Chinyio, E. A., \& Olomolaiye, P. O. (2012). Design of a sustainable building: A conceptual framework for implementing sustainability in the building sector. Buildings, 2(2), 126-152.

Al-Kodmany K. (2018) The vertical city: A sustainable development model. WIT Press.

Al-Kodmany, K. (2015) Eco-Towers: Sustainable Cities in the Sky. WIT Press.

Al-Kodmany, K., \& Ali, M. M. (2013). The future of the city: Tall buildings and urban design. WIT press.

Auclair, E., \& Hertzog, A. (2015). High-rise Estates, Industrial Tenements and Social Housing: Concerns and Controversies Around Inhabited Heritage Sites. Introduction. EchoGéo, (33).

Butkovic, A., Brkovic, I., \& Bratko, D. (2012). Predicting well-being from personality in adolescents and older adults. Journal of Happiness Studies, 13(3), 455-467.

Dizayee, R. H. (2014). Groundwater Degradation and Sustainability of the Erbil Basin, Erbil, Kurdistan Region, Iraq. Texas Christian University, Fortworth, Texas.

Dodge, R., Daly, A. P., Huyton, J., \& Sanders, L. D. (2012). The challenge of defining well-being. International Journal of Wellbeing, 2, 222-235.

Erbil Governorate Profile. (2015). [Online] Available: http://reliefweb.int/sites/reliefweb.int/files/reso urces/Erbil_governorate_profile_May_2015.p df (Accessed 26 Aug. 2017).

Garling TFM (2002). "APsychological Conceptualization of Residential Choice and Satisfaction, in: J. I. Aragon'es, G. FrancescatoandT." Residential Environments: Choice, Satisfact. Behav., pp. 55-80.

Gissen, D., Ed.; Princeton Architectural Press: New York, NY, USA, 2003; pp. 10-17.
Giudice, F.; La Rosa, G.; Risitano, A. (2005) Materials selection in the Life-Cycle Design process: A method to integrate mechanical and environmental performances in optimal choice. Mater and Design. 26(1), 9-20

Grillo, M., Teixeira, M., \& Wilson, D. (2010). Residential satisfaction and civic engagement: Understanding the causes of community participation. Social Indicators Research, 97(3), 451-466.

Haarhoff, E., Beattie, L., \& Dupuis, A. (2016). Does higher density housing enhance liveability? Case studies of housing intensification in Auckland. Cogent Social Sciences, 2, 1243289.

Haarhoff, E., Beattie, L., Dixon, J., Dupuis, A., Lysnar, P., \& Murphy, L. (2013, November). Future Intensive: Obstacles and opportunities to achieving the compact urban form in Auckland. In Proceedings of the National Conference of the State of Australian Cities, Sydney, 26-29 November.

Haarhoff, E., Beattie, L., Dixon, J., Dupuis, A., Lysnar, P., \& Murphy, L. (2012). Future intensive: Insights for Auckland's housing. Auckland: The University of Auckland; Transforming Cities

Heinonen, J.; Kyrö, R.; Junnila, S. (2011) Dense downtown living more carbon intense due to higher consumption: A case study of Helsinki. Environment Research., 6, pp. 1-9

Hua Kiefer, M.A., 2007. Essays on applied spatial econometrics and housing economics. Ph.D. Thesis, Ohio State University, USA.

Ibrahim, E. (2007). High-Rise Buildings-Needs \& Impacts. In CIB World Building Congress (Vol. 2007).

Ibrahim, R. I., Mushatat, S. A., \& Abdelmonem, M. G. (2015). Erbil. Cities, 49, 14-25. DOI: 10.1016/j.cities.2015.07.001

James, R., III, Carswell, A., \& Sweaney, A. (2009). Sources of discontent: Residential satisfaction

wezha.hawez@gmail.com; ercan.hoskara@emu.edu.tr

${ }^{1}$ Corresponding author: Faculty of Architecture, Eastern Mediterranean University, North Cyprus, Famagusta 99450, Mersin 10, Turkey 
of tenants from an internet ratings site.

Environment and Behavior, 41(1), 43-59.

Kawamoto, Y. (2016). Effect of urbanization on the urban heat island in Fukuoka-Kitakyushu metropolitan area, Japan. Procedia Eng, 169(9), 224-231

Leventhal T, Brooks-Gunn J. The neighborhoods they live in: The effects of neighborhood residence on child and adolescent outcomes. Psychological Bulletin. 2000; 126:309-337.

Lynch, E. (2015). Hurricane Sandy's Wake-Up Call. Planning, 81(2), 26-30.

Prezza, M.; Amici, M.; Roberti, T.; Tedeschi, G. (2001) Sense of community referred to the whole town: Its relations with neighboring, loneliness, life satisfaction, and area of residence. Journal of community psychology, 29, pp. 29-52.

Rydin, Y. (2010). Governing for sustainable urban development. London: Earthscan.

Salassa, J. R., \& Zapala, D. A. (2009) Love and fear of heights: the pathophysiology and psychology of height imbalance. Wilderness \& environmental medicine, 20(4), pp. 378-382De.

Story, L.; Saulfeb, S. Stream of ForeignWealth Flows to Elite New York Real Estate. The New York Times. [Online] Available: https://www.nytimes.com/2015/02/08/nyregio $\mathrm{n} /$ stream-of-foreign-wealth-flows-totime-warn er-condos.html?_r=0. (accessed on 15 April 2018).

Strauss, A., \& Corbin, J. (1998). Basics of Qualitative Research: Techniques and Procedures for Developing Grounded Theory (2nd ed.).
Thousand Oaks, London, New Delhi: Sage Publications.

Syme, G. J., Shao, Q., Po, M., \& Campbell, E. (2004). Predicting and understanding home garden water use. Landscape and Urban Planning, 68(1), 121-128.

Turner R and Wigfield A. (2017) It's time to recognise how harmful high-rise living can be for residents. [Online] Available: https://theconversation.com/its-time-torecognise-how-harmful-high-rise-living-can-b e-for-residents-87209 (Accessed 26 Nov. 2019).

Watts, S., \& Langdon, D. (2010). The Economics of High-Rise as Per 2nd Quarter 2010. CTBUH Journal Issue III Tall Buildings in Numbers, 44-45.

Wood, A., Oldfield, P. Global Trends in High-Rise Design. [Online] Available: http://www.nottingham.ac.uk/ lazwww/projec ts/TallBuildings_2008_Web/about_tab_modul e/images/GlobalTrends_UrbanismArchitecture .pdf (accessed on 10 June 2015).

Woodward, D.G (1997). Life cycle costing-Theory, information acquisition and application. Proj. Manag. 1997, 15, 335-344.

Yasin, S. (2011). Influence of modernity versus continuity of architectural identity on house facade in Erbil City, Iraq. Ph.D. Thesis. Sains Malaysia University, Pulau Pinang Malaysia.

Yuen, B. (2011). Liveability of tall residential buildings. In High-rise living in Asian cities (pp. 129-147). Springer, Dordrecht.

wezha.hawez@gmail.com; ercan.hoskara@emu.edu.tr 